\title{
Assessment on Incidence and Severity of White Rote Associated with Agronomic Practice and Environmental Factors at North Shewa, Central Highlands of Ethiopia
}

\author{
Zenebu Shewakena ${ }^{1}(\mathrm{MSc}$. \\ Department of Plant Sciences, College of Agriculture and Natural Resource, \\ Bonga University PO Box 334 Bonga, Ethiopia \\ Negash Hailu² (Phd) \\ Bizzuhaman Desta ${ }^{2}$
}

\begin{abstract}
White rot of garlic caused by a soil borne fungus (Sclerotium cepivorum Berk) is a major production threat of garlic in Ethiopia and all over the world. During favorable weather conditions, and when susceptible varieties are in the production system, the disease can cause $100 \%$ yield loss. Furthermore, sclerotium cepivorum is an issue of great importance for dry climate producers. Its intensity also vary with different cultural practices and environmental factors. The study was initiated with the objectives of assessing the incidence and severity of garlic white rot associated with environmental factors and cultural practices under dry season in North Shewa, Amhara Region, Ethiopia. To assess production practices, data were collected using multistage sampling technique from 40 garlic producing households. The data necessary for the study was collected from those sampled garlic producers by using a structured interview. In each sampled producers, three quadrants $(0.5 \mathrm{~m}$ by $0.5 \mathrm{~m}) 2-3 \mathrm{~m}$ apart were taken by making diagonal moves in the field. Then, incidence of white rot was assessed by counting the number of plants showing white rot symptoms in each quadrant and averages were taken for each field. The assessment results showed that about $97 \%$ of the fields were infested with white rot. Disease incidence was varied among districts, altitude range, temperature, soil type and field management practices. However, the mean disease incidence and severity were higher in Menz Mama Midir as compared to the other districts.
\end{abstract}

Keywords: garlic, Sclerotium cepivorum, white rot, district

DOI: $10.7176 / \mathrm{JAAS} / 62-02$

Publication date:March $31^{\text {st }} 2020$

\section{Introduction}

Garlic (Allium sativum L.) is widely produced for its culinary properties and medicinal role for centuries such as antibacterial, antifungal, antiviral, antitumor and antiseptic properties (Deresse, 2010). Antibacterial and antiseptic property of garlic is well known and it contains remedies against headache, bites, worms and tumors (Keusgen, 2002). In addition, it has antibiotic properties, and it can lower blood pressure, blood cholesterol and blood sugar, prevent blood clotting, protect the liver and contains antitumor properties (Sovova and Sova, 2004). Economic significance of garlic in Ethiopia is fairly considerable and contributes to the national economy as export commodity (Dilbo et al., 2015; Fekadu and Dandena, 2006).

World garlic cultivation was increased from 771,000 ha of land in 1989/90 to 1,204,711 ha of land in 2007 with total production from 6.5 million to 15.68 million tons, and productivity from $8.43 \mathrm{t} / \mathrm{ha}$ and $13.02 \mathrm{t} / \mathrm{ha}$, respectively (FAO, 2007). In Ethiopia, garlic production was increased from 6,042 ha in 2012 to 21,258 ha of land in 2013 with a total production increment from 79,421 to 222,548 tons of bulbs (CSA, 2013). However, garlic cultivation decreased from $16,411.19$ ha in $2013 / 14$ to 15,381 ha in $2016 / 17$ with a total production of $159,093.58$ and $138,664.3$ tons of bulbs with the productivity of 9.7 and 9.01 tha $^{-1}$, respectively(CSA, 2017).

The reduction of garlic production in many parts of the world is due to a variety of diseases and disorders. Among the disease, the main limiting factor for onion and garlic production is the white rot disease caused by breaking of floral stalks, and thus, the bulb yield and seed production is significantly reduced (Bo Ming et al.,2010). Sclerotium cepivorum has caused great damage in diverse growing regions worldwide, and causes serious economic losses in garlic and onion crops. In Mexico and in Brazil, losses up to 100\% were reported. The disease is also serious in Canada and incidence was exceeding up to $65 \%$ in commercial fields (Wiley and Sons, 2000). In Ethiopia, yield loss due white rot has been found to range between $20.7 \%$ and $53.4 \%$ (Tamire et al., 2007). The low production and productivity of garlic in Ethiopia in general and in Amhara region in particular are also the results of inappropriate agronomic practices, absence of proper diseases and insect pest managements and lack of improved varieties are the most important factors (Tesfaye and Habtu, 1986; Teweldebrhan, 2009; Worku and Dejene, 2012). Host and soil effects are important in the survival of white rot. Among soils, wet soil like vertisol increased the disease incidence provided that the inoculum level was sufficient in the soil. Sclerotial 
germination is also poor during the winter but improves in spring and early summer; later in the summer, germination may be inhibited by high soil temperatures. On average, the temperature ranged from 7 to $22{ }^{\circ} \mathrm{C}$ which was suitable for sclerotial germination and disease development (Tamire et al., 2007). On the other hand, the hardwalled sclerotia formed during infection are incredibly tough, and can remain dormant yet viable in the soil for many years (Maude, 2006), some evidence suggesting up to two decades (Mueller et al., 2006), meaning that once a field is infested with sclerotium cepivorum, Allium cultivation may not be possible there for many years (Amine et al., 2013). Therefore, the objective of this study was to assess the incidence and severity of white rot associated with environmental factors and different agronomic practices.

\section{MATERIALS AND METHODS}

\subsection{Description of Experimental Site}

Field survey was conducted in four districts of Menz Mama Midr, Moretna Jiru, Ensaro and Angolelana Tera during the off season of 2018 planted using irrigation (Fig 1). Menz Mama Midr is located at an altitude range from 2500 to 3500 m.a.s.l. It receives average annual rain fall of 1000 to $1500 \mathrm{~mm}$ with temperature of 15 to 20 ${ }^{\circ} \mathrm{C}$. Ensaro is located between $9^{\circ} 35^{\prime}-9^{\circ} 55^{\prime} \mathrm{N}$ and $38^{\circ} 50^{\prime}-39^{\circ} 5^{\prime} \mathrm{E}$ with an average elevation of $2435 \mathrm{~m}$.a.s.1. AngolelanaTera is located at $9.28^{\circ} \mathrm{N}, 39.23^{\circ} \mathrm{E}$ and at an altitude range of 2756 to $4326 \mathrm{~m}$.a.s.l. Its average annual rainfall is ranged from 900 to $1500 \mathrm{~mm}$ with temperature of 18 to $30^{\circ} \mathrm{C}$. Moretna Jiru is located at $39^{\circ} 19^{\prime} 24^{\prime}$ ' $\mathrm{E}$ and $10^{\circ} 6^{\prime} 2^{\prime} ' \mathrm{~N}$ at an altitude ranges from 1,500 to $2664 \mathrm{~m}$.a.s.l. and receives an annual rainfall of $850 \mathrm{~mm}$ while the temperature varies from $5.2^{\circ} \mathrm{C}$ to $28.8^{\circ} \mathrm{C}$.

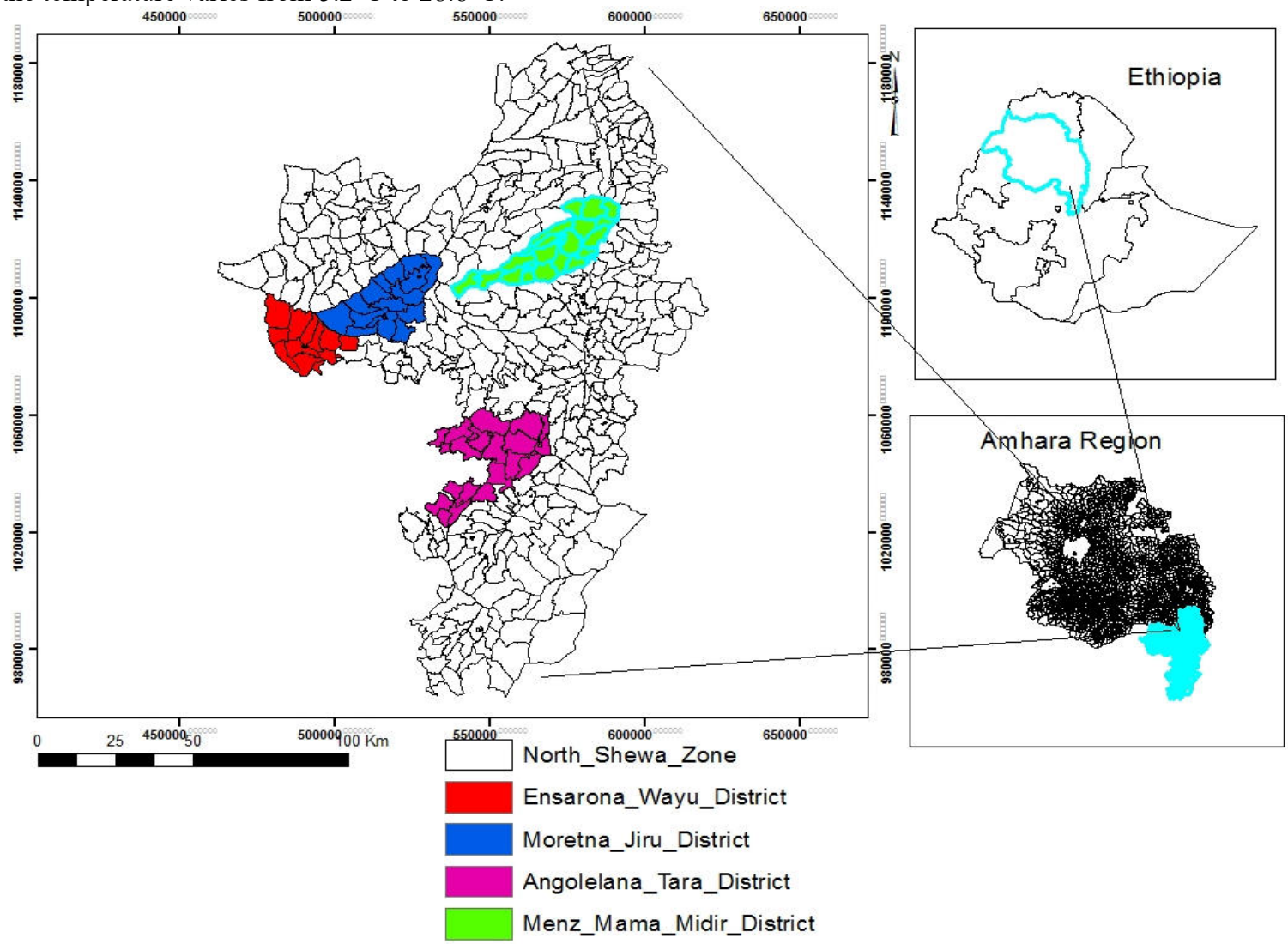

Figure 1. Map of four districts in North Shewa where the survey was conducted

\subsection{Field Survey Sampling Technique and Method of Data Collection}

Field survey was conducted by using multistage sampling technique. Four potential garlic production districts of north Shewa Zone namely Menz Mama Midir, Angolelana Tera, Moretna Jiru and Ensaro were selected with the consultation of zonal agricultural experts. Seven peasant associations, one from Angolelana Tera district, two from Menz Mama Midir, two from Moretna Jiru and two from Ensaro districts were chosen purposively. The farm households in each PAs were stratified in to garlic producers using irrigation and non-producers. Generally, a total of 40 garlic producers using irrigation were randomly selected from each districts; i.e. 16, 11, 10 and 3 garlic producers from Menz Mama Midir, Moretna Jiru, Ensaro and Angolelana Tera respectively. The data necessary for the study was collected from those sampled garlic producers by using a structured interview. In each sampled 
producers, three quadrants $(0.5 \mathrm{~m}$ by $0.5 \mathrm{~m}) 2-3 \mathrm{~m}$ apart were taken by making diagonal moves in the field. The plants in each quadrant were taken as the sample unit. The plant population in each quadrant was counted and average plant population in the three quadrants was taken as mean plant population density. Incidence of white rot was assessed by counting the number of plants showing white rot symptoms (such as yellowing, discoloration, bulb rotting and presence of mycelium and/or sclerotia around the base of the plant) in each quadrant and averages were taken for each field. White rot severity was also recorded by observing the level of white rot damage with 0 5 scale and converted to percentage. During the survey, altitude $(\mathrm{m})$, type of soil, cropping pattern (row or broadcast planting), previous crop, planting date and plant density were recorded for each sampled field.

\subsection{Field survey analysis}

Descriptive way of analysis was conducted to describe the distribution, prevalence and association of white rot incidence and severity in relation to altitude, temperature, soil type and agronomic practice. Distribution and severity of white rot was discussed in each districts by recording mean, range and frequency in each variables.

\section{RESULTS AND DISCUSSION}

\subsection{White rot Incidence and Severity by districts}

White rot incidence and severity were recorded on garlic local cultivars from four districts (Table 1). The mean incidence and severity of garlic white rot was highest at Menz Mama Midr with altitude range of 2500-3500 as compared to the other districts m.a.s.l. This indicated that this altitude range might be favorable for the disease distribution and germination of sclerotia and hyphal growth. Crowe (2008) and Ararsa and Thangavel (2013) also reported that cool weather is needed for germination of sclerotia and hyphal growth. Tamire et al. (2007) reported that with white rot disease incidence increased as elevation increased from 2450 to 3350 m.a.s.l.

Variation of temperature related to altitude was also resulted in difference mean incidence and severity of white rot. The mean minimum incidence $(20.2 \%)$ was obtained from temperature ranged from $6-17{ }^{\circ} \mathrm{C}$. On the other hand, the mean maximum incidence $(51.36 \%)$ and severity $(39.74 \%)$ were from temperature ranged from $15-20{ }^{\circ} \mathrm{C}$ (Table 1). Similar with this, Tamire et al. (2007) reported that on average, the existence of favorable temperature ranged from 7 to $22{ }^{\circ} \mathrm{C}$ was suitable for sclerotial germination and disease development. Crowe and Hall (1980) also reported that sclerotial germination occurs between 9 and $24^{\circ} \mathrm{C}$ and disease development between 6 and $24^{\circ} \mathrm{C}$.

Table 1. Distribution and severity of garlic white rot in four districts

\begin{tabular}{llllllll}
\hline Districts & Altitude & Temperature & \multicolumn{3}{c}{ Severity } \\
\cline { 4 - 8 } & $(\mathrm{m})$ & $\left({ }^{\circ} \mathrm{C}\right)$ & Frequency & Range & Mean & Range & Mean \\
\hline Angolelana Tera & $2756-4326$ & $6-17$ & 3 & $9.38-31.03$ & 20.20 & $20-20$ & 20 \\
Ensaro & 2435 & $18-30$ & 10 & $6.00-90$ & 43.77 & $20-74$ & 34.39 \\
Menz Mama idir & $2500-3500$ & $15-20$ & 16 & $8.0-90.91$ & 51.36 & $20-71$ & 39.74 \\
Moretna Jiru & $1500-2664$ & $5.2-28.8$ & 11 & $11.76-84.85$ & 48.34 & $20-41.05$ & 29.28 \\
\hline
\end{tabular}

\subsection{Association of White rot with Soil Type}

The variation in incidence and severity of white rot among districts could be resulted from differences in soil type. The soil type in major garlic fields of Menz Mama Midir and Moretna-Jiru is a vertisol compared to the other two districts. The soil type in Ensaro and Angolelana-Tera districts is silt soil. However, disease incidence in vertisol was ranged from $11.76 \%$ to $90.91 \%$. Higher severity (34.18\%) was also recorded on this soil type (Table 2). This might be due to the vertisol having a characteristic of conserving more moisture with low temperature; which favored for white rot sclerotioa. In agreement with this, Tamre et al. (2007) reported that vertisol favored for the occurrence of white rot. Clarkson et al. (2006) also identified that Sclerotium cepivorum sclerotia rely on moderate soil moisture to germinate. Moderate-to-high soil moisture favoring germination and infection, though some research had suggested sclerotial germination is fairly independent of soil moisture content (Maude, 2006).

Table 2. Incidence and severity of garlic white rot associated with soil type

\begin{tabular}{llllll}
\hline Soil type & \multicolumn{3}{c}{ Incidence } & \multicolumn{2}{c}{ Severity } \\
\cline { 2 - 6 } & Frequency & Range & Mean & Range & Mean \\
\hline Clay loam & 7 & $23-85$ & 39.74 & $20-71$ & 30.14 \\
Silt & 13 & $6.90-90.91$ & 41.71 & $20-74$ & 28.88 \\
Vertisol & 19 & $11.76-90.91$ & 55.56 & $20-61.2$ & 34.18 \\
\hline
\end{tabular}

\subsection{Association of White rot with Agronomic Practices}

Agronomic practices such as plant density, previous crop history, planting date and cropping pattern (row or broadcast) were practiced differently within each district. During the survey, it had been observed that higher number of infected plants with white rot symptoms were recorded in densely populated $\left(\geq 25\right.$ plants $\left.0.25 \mathrm{~m}^{-2}\right)$ fields than in sparsely populated $\left(<25\right.$ plants $\left.0.25 \mathrm{~m}^{-2}\right)$ fields. The mean maximum incidence and severity recorded from 
lower plant density were lower as compared to higher plant density (Table 13). This could be due to more plant to-plant spread of the Sclerotium cepivorum. This was in agreement with Tamire et al. (2007) who reported that higher number of infected plants with white rot symptom was recorded from densely populated fields than in sparsely populated fields. Similarly, mean incidence (44\%) and severity $(35.73 \%)$ recorded from garlic crop planted in January were lower as compared to mean incidence $(48.34 \%)$ and severity $(38.94 \%)$ recorded from November, which might be due to the distribution and severity level of the disease become increased as crop growth increased (Table 3). In line with this, Amin et al. (2014) reported that disease symptom had increased from mid-season to harvest of the crop.

In the surveyed fields, garlic was planted in rotation with different crops. Of the total surveyed fields, 8 fields were continuously planted with garlic. The higher mean of incidence $(77 \%)$ and severity $(57 \%)$ were recorded from fields from which garlic crop was continuously grown (Table 13). Continuous growing of garlic leads to accumulation of the white rot sclerotia in the soil that increases the occurrence of white rot (Tamire et al., 2007). Once the bulb is infected, the plant soon loses vigor, the leaves become yellow and wilt, and fluffy, white mycelia fill the bulb and then produce abundant sclerotia to precipitate future infections (Maude, 2006; Mueller et al., 2006).

Disease incidence and severity also vary with cropping pattern. The mean disease incidence and severity in broadcast cropping pattern was $48.69 \%$ and $46.68 \%$, respectively. On the other hand, mean disease incidence (44.91\%) and severity (33.25\%) in row cropping pattern was lower than broadcasting (Table 13 ). In broadcast cropping system of garlic, crop density was higher than row planting, which might be due to the increase in colonizing of the disease from infected plant to uninfected plant. Crowe (2008) also reported that uninfected roots within 1 to $2 \mathrm{~cm}$ of infected roots in contact with infected roots get colonized by hyphae from infected roots.

Table 2. Incidence and severity of garlic white rot associated with agronomic practices

\begin{tabular}{llllllll}
\hline \multirow{2}{*}{ Agronomic practice } & & Incidence & \multicolumn{3}{c}{ Severity } \\
\cline { 3 - 7 } & & Frequency & Range & Mean & Frequency & Range & Mean \\
\hline Plant density & High & 12 & $11-90.91$ & 52.92 & 12 & $20-71$ & 34.15 \\
& Low & 27 & $6.9-90.91$ & 42.89 & 27 & $20-61.2$ & 33.79 \\
Previous crop & Cereal & 11 & $6.9-55.56$ & 11.76 & 11 & $20-33.3$ & 30.32 \\
& Fallow & 15 & $8-84.85$ & 37.3 & 15 & $20-60$ & 39.84 \\
& Garlic & 8 & $48.6-90.9$ & 77 & 8 & $24-60$ & 57 \\
Planting date & Vegetable & 5 & $20-87.88$ & 57 & 5 & $22-71$ & 34.46 \\
& January & 20 & $6.9-85.29$ & 44 & 20 & $20-71$ & 35.73 \\
Cropping patternyyyyyyy & November & 19 & $8-90.91$ & 48.34 & 19 & $20-71$ & 38.94 \\
& Broadcast & 28 & $8.0-90.91$ & 48.69 & 28 & $20-61.2$ & 46.68 \\
& Row & 11 & $6.9-87.88$ & 44.91 & 11 & $20-41.5$ & 33.25 \\
\hline
\end{tabular}

\section{SUMMARY, CONCLUSION AND RECOMMENDATION}

In Ethiopia, garlic (Allium sativum L.) is one of the most widely grown bulb crops next to onion and it is grown under a wide range of climatic and soil adaptation. However, its production and productivity is reduced due to many factors of which diseases and improper agronomic practices are economically important problems. Distribution of the disease is varied in different areas on different altitudes, temperature range, soil types and agronomic practices. In the present study, the assessment was conducted to assess the incidence and severity of garlic white rote associated with environmental and cultural practices. Field survey was conducted in four districts of North Shewa (Menz Mama Midr, Moretna Jiru, Ensaro and Angolelana Tera) of irrigation user areas in 2018 cropping season. It was conducted by considering selective factors, which were suggested as a main reason for increasing the incidence and severity of garlic white rot. The survey result indicated that incidence and severity of white rot were affected by environmental factors and agronomic practices. Higher white rot incidence and severity were coincided with altitude of $2500-3500$ m.a.s.1, 15-20 ${ }^{\circ} \mathrm{c}$ temperature and vertisol type. In addition, the higher incidence and severity were strongly related with improper agronomic practiced fields. The higher number of infected plants with white rot symptoms were recorded in densely populated ( $\geq 25$ plants $0.25 \mathrm{~m}^{-2}$ ) fields than in sparsely populated $\left(<25\right.$ plants $\left.0.25 \mathrm{~m}^{-2}\right)$ fields. Higher mean of incidence $(77 \%)$ and severity $(57 \%)$ were also recorded from fields from which garlic crop was continuously grown. In broadcast cropping system of garlic, crop density was higher than row planting and highest percentage of disease incidence $(48.69 \%)$ and severity $(46.68 \%)$.

Farmers should follow a long-term rotation schedule, and do not follow Allium crops with other Allium crops. Rotation alone will not control white rot because sclerotia can survive in soil for more than two decades. Use of row spacing with reduced plant density per row is also reduce the colonizing of pathogen from infected plant to healthy plant. In addition, farmers should be plant only clean stock from known origins that have no history of white and always clean the soil off of equipment before moving from one field to another and it is better to use the clay loam or silt as compared to vertisol for garlic production purpose. 


\section{REFERENCES}

Agegnehu Shibabaw, Wallelign Zegeye, Bayuh Belay, Fikremariam Asaregew, Abebe Worku, Dereje Belay, Esmelalem Mehretu and Getachew Alemayehu.2013. Diseases, insect pests and parasitic weeds of common crops and their importance under irrigation conditions of Rib areas. aizen publishers Vol.1 Pp 262-265.

Amin Mohammed Tadele Shiberu and Thangavel S. 2014. White rot (Sclerotium cepivorum Berk)-an aggressive pest of onion and garlic in Ethiopia: An overview. Journal of Agricultural Biotechnology and Sustainable Development. 6(1):6-15.

Ararsa, L. and Thangavel, S. 2013. Evaluation of Arbuscular Mycorrhizal Fungi and Trichoderma Species for the Control of Onion White Rot (Sclerotium cepivorum Berk), in Ambo university, Ethiopia. Journal of Plant Pathology and Microbiology. 2157-7471(4):159

Chemeda Dilbo, Melaku Alemu, Alemu Lencho and Tariku Hunduma. 2015. Integrated Management of Garlic White Rot (Sclerotium cepivorum Berk) Using Some Fungicides and Antifungal Trichoderma Species. Journal of Plant Pathology and Microbiology. 6(1): 251. doi:10.4172/2157-7471.1000251.

Clarkson, J.P., Scruby, A., Mead, A., Wright, C. and Smith, B. 2006. Integrated control of Allium white rot with Trichodermaviride, tebuconazole and composted onion waste. Journal of Plant Pathology. 5(24): 375-386.

Crowe, F.J. 2008. White Rot in compendium of onion and garlic diseases and pests. Schwartz, J. Fed. APS Press, St. Paul, MN. pp. 22-26.

CSA (Central Statistical Agency). 2013. The Fedral Democratic Republic of Ethiopia Central Statistical Agency Report on Area and Production of Major Crops, I, 13-14.

CSA (Central Statistical Agency). 2017. Agricultural Sample Survey of 2016/17. Report on area and production of major crops (Private Peasant Holdings, Meher season). Addis Ababa, April 2017. Stat. Bull.584:1

Deresse Daka. 2010. Antibacterial effect of garlic (Allium sativum) on Staphyloccusaureus: An Invitro study. Asian Journal of Medical Sciences. 2(10): 62-65.

Diriba Shiferaw, Nigussie Dechassa, Woldetsadik Kebede, Getachew Tabor and Sharma, J.J. 2013. Postharvest Quality and Shelf life of Garlic Bulb as Influenced by Storage Season, Soil Type and Different Compound Fertilizers. Journal of Postharvest Technology. 01(01): 069-083.

Fekadu Mariame and Dandena Gelmesa. 2006. Review of the status of vegetable crops production and marketing in Ethiopia. Uganda Journal of Agricultural Sciences. 12 (2): 26-30.

Keusgen, M. 2002. Health and Alliums, In H.D. Rabinowitch and L.Currah, eds. Allium crop science: Recent advances. CAB International, Walling ford, UK.

Maude, R.B. 2006. Onion Diseases. In: The Epidemiology of Plant Diseases, Cooke BM, Jones DG and Kaye B, (Eds.), Vol 19. Springer, USA.

Mueller, S., Hembree, K., Molinar, R. and Schwank1, L. 2006. Garlic white rot Trial, 2005/2006 progress report. Retrieved from http://cagarlicandonion.com/page/1003/resources.html. Accessed on April 15, 2018.

Sovová, M. and Sova, P. 2004. Pharmaceutical importance of Allium sativum L. Hypolipemic effects in-vitro and in-vivo (in Ceska. Slov. Farm). 10:244-251.

Tadesse Adgo. 2008. Farmers' evaluation and adoption of improved onion production package in Fogera district. M.Sc. Thesis, Haramaya University, Haramaya, Ethiopia.

Tamire Zewde, Chemeda Fininsa and Sakhuja K.P. 2007. Management of white rot (Sclerotium cepivorum) of garlic using fungicides in Ethiopia. Department of Plant Sciences. 26 (2007): 856-866.

Tamire Zewde, Chemeda Fininsa, Sakhuja K.P. and Ahmed Seid. 2007. Yield loss assessment of garlic due to white rot (Sclerotium cepivorum) in Ethiopia.

Teklu Erkosa, Teklewold Hailemariam. 2009. Agronomic and economic efficiency of manure and urea fertilizers use on Vertisols in Ethiopian Highlands. Agricultural Science in China 8(3): 352-360.

Worku Mengesha, Mashilla Djene and Azene Tesfaye. 2015. Effectiveness of fungicides to control garlic rust (puccinia allii (rudolphi.)) at Haramaya, Eastern Ethiopia. International Journal of Advanced Agricultural Research. 1(1):16-22. 